\title{
Competition of pigweed (Amaranthus dubius) with sweetpotato (Ipomoea batatas)'
}

\author{
Nelson Semidey, Lii C. Liu and Francisco H. Ortiz
}

\begin{abstract}
Two field experiments were sonducted at the Isabela and Juana Diaz Research Centers in 1982-83 to determine the effect of pigweed ( Amaran thus dubius Mart.) density on yield of sweetpotato [ lpomoea batatas (L.) Lam]. Pigweed densities of $0,4,7,13$ and 27 plants $/ \mathrm{m}^{2}$ were adjusted by hand at Isabela and those of $0,11,23,45$ and 91 plants $/ \mathrm{m}^{2}$ were main. tained at Juana Díaz. Pigweed population averaged 27 plants $/ \mathrm{m}^{2}$ at Isabela and 91 plants $/ \mathrm{m}^{2}$ at Juana Díaz under natural infestation. Sweetpotato yield was reduced significantly from 4 plants $/ \mathrm{m}^{2}$ at Isabela and from 11 plants $/ m^{2}$ at Juana Díaz. The highest sweetpotato yield was obtained on weed-free plots with $11,823 \mathrm{~kg} / \mathrm{ha}$ at Isabela and $27,724 \mathrm{~kg} / \mathrm{ha}$ at Juana Díaz. The greatest yield reduction $(91 \%)$ resulting from pigweed competition (at Juana Diaz) was at a density of 91 plants $/ \mathrm{m}^{2}$. At Isabela, a density of 13 plants $/ \mathrm{m}^{2}$ caused the greatest yield reduction $(78 \%)$. The effect of pigweed on number of root-tubers followed a similar trend as the effect on yield. Dry weight of pigweed per plant was significantly greater at population densities of 4 and 7 plants $/ \mathrm{m}^{2}$ at Isabela. At Juana Diaz, dry weight of pigweed was significantly higher at a population density of 11 plants $/ \mathrm{m}^{2}$. The regression between sweetpotato yield and the different population densities of pigweed showed an inverse linear relationship at both localities.
\end{abstract}

\section{INTRODUCTION .}

Sweetpotato [Ipomoea batatas (L.) Lam.] is an important root crop in Puerto Rico. More than 10,000 metric tons of sweetpotato are produced annually with a gross ineome of $\$ 3.02$ million (2). Sweetpotato is known as a highly competitive crop against weeds (9). However, this crop is susceptible to weed competition during the first 2 months of growth. As soon as the canopy of sweetpotato becomes established, it will overcome competition from weeds. Weed-crop competition research has been focused on the study of critical periods of competition but individual weed species involved are not indicated $(6,11)$.

The Amaranthaceae family includes the most important weeds in the United States and the Tropics $(1,5)$. The adverse effects of pigweed density on yield has been studied in different crops $(4,8,11)$. For example, at a population of 1 plant per $2.43 \mathrm{~m}$ of crop row, pigweed reduced soybean yield by $30 \%$ (4). At the same time 32 plants per $2.43 \mathrm{~m}$ of crop

'Manuscript submitted to Editorial Board July 2, 1986.

${ }^{2}$ Research Assistant; Plant Physiologist, Department of Crop Protection and Assistant Agronomist, Department of Horticulture, Agricultural Experiment Station, Mayagüez Campus, University of Puerto Rico, Río Piedras, P. R. 
row, reduced soybean yield by about $72 \%$. In tomato, at a population density of 1 plant per $3 \mathrm{~m}$ of row, Amaranthus retroflexus reduced yield $30 \%$ (8). The most common pigweed species in Puerto Rico is A. dubius Mart. This weed was found to produce more than 19,000 seeds per plant with a $23 \%$ field germination (7). The above-mentioned information has pointed out the potential danger of pigweed prevalence in our crops.

In a previous publication (10) we reported the effect of junglerice [Echinochloa colonum (L.) Link] on the yield of sweetpotato. The yield was not reduced significantly by junglerice at densities lower than 10 plants per square meter. The objective of this study was to determine the effect of pigweed density on yield of sweetpotato.

\section{MATERIALS AND METHODS}

Two field experiments were conducted at the Isabela and Juana Diaz Research Centers in 1982-83. The soil at Isabela was a Coto clay (34.8\% sand, $21.6 \%$ silt and $43.6 \%$ clay) with a $\mathrm{pH}$ of 6.8 and an organic matter content of $3.59 \%$. The soil at Juana Díaz was a San Antón loam (38.4\% sand, $37.2 \%$ silt and $24.4 \%$ clay) with a $\mathrm{pH}$ of 7.3 and an organic matter content of $2.1 \%$. The experimental plots consisted of four rows $(6.1 \mathrm{~m}$ long and 1.2 apart) arranged in a partially balanced incomplete block design with four replications. The sweetpotato vines of Miguela cultivar were planted on the ridge August 1982. The fields at both localities were irrigated at approximately $2.54 \mathrm{~cm}$ of water immediately after planting. Periodic irrigation was supplied to maintain optimum growth. Pest management and fertilization practices were performed following the reemmendations of the Experiment Station (3).

Weeds were allowed to grow for the first 2 to 3 weeks after planting. Pigweed population averaged 27 plants $/ \mathrm{m}^{2}$ at Isabela and $91 \mathrm{plants} / \mathrm{m}^{2}$ at Juana Díaz under natural infestation conditions. Weeds other than pigweed were removed from plots periodically. Pigweed population was adjusted by hand at desired densities. Pigweed densities of $0,4,7,13$ and 27 plants $/ \mathrm{m}^{2}$ were maintained at Isabela; and those of $0,11,23,45$ and $91 \mathrm{plants} / \mathrm{m}^{2}$ at Juana Díaz. A weedy check was also included in both experiments. Fresh and dry weight of pigweed were determined by sampling 10 plants per plot 2 weeks before harvest. Sweetpotatoes were harvested 5 months after planting. Roots of $0.2 \mathrm{~kg}$ or more were harvested to determine yield. Analysis of variance and $t$-test were used to compare treatment means. Regression analysis was made to determine the relationship between yield and population density of pigweed.

\section{RESULTS AND DISCUSSION}

Sweetpotato yield was reduced significantly by pigweed population densities beginning at 4 plants $/ \mathrm{m}^{2}$ at Isabela and 11 plants $/ \mathrm{m}^{2}$ at Juana Díaz (tables 1 and 2). The highest yield reduction (78\%) because of pig- 
TABLE 1.-Effect of pigweed ( $P W$ ) population densities on yield of sweet potato at 1sabela

\begin{tabular}{cccc}
\hline $\begin{array}{c}\text { PW density } \\
\text { (plants/m }\end{array}$ & $\begin{array}{c}\text { PW dry weight } \\
\text { (g/plant) }\end{array}$ & \multicolumn{2}{c}{ Sweet potato yield ${ }^{2}$} \\
\cline { 3 - 4 } & - & $\mathrm{Kg} / \mathrm{ha}$ & N. tubers $/ \mathrm{ha}$ \\
\hline 0 & $54.2 \mathrm{a}$ & $11,823 \mathrm{a}$ & $23,754 \mathrm{a}$ \\
4 & $48.5 \mathrm{a}$ & $6,60 \mathrm{~b}$ & $16,059 \mathrm{~b}$ \\
7 & $26.8 \mathrm{~b}$ & $4,980 \mathrm{bc}$ & $15,892 \mathrm{~b}$ \\
13 & $21.8 \mathrm{~b}$ & $2,611 \mathrm{c}$ & $9,368 \mathrm{c}$ \\
27 & $28.5 \mathrm{~b}$ & $4,332 \mathrm{bc}$ & $14,888 \mathrm{bc}$ \\
Weedy cheek & 35 & $1,040 \mathrm{c}$ & $5,018 \mathrm{c}$ \\
CV $(\%)$ & 51 & 52 \\
\hline
\end{tabular}

Means followed by the same letters do not differ significantly at $\mathrm{P}=.05$ using the paired- $t$ test.

TABLE 2.-Effect of pigweed ( $P W$ ) population densities on yield of sweet potato at Juana Diaz

\begin{tabular}{cccc}
\hline \multirow{2}{*}{$\begin{array}{c}\text { PW density } \\
\text { (plants/m } \text { f }^{2}\end{array}$} & $\begin{array}{c}\text { PW dry weight } \\
\text { (g'plant) }\end{array}$ & \multicolumn{2}{c}{ Sweet potato yield } \\
\cline { 3 - 4 } & - & Kg/ha & N. tubers/ha \\
\hline 0 & $34.5 \mathrm{a}$ & $3,795 \mathrm{~b}$ & $42,489 \mathrm{a}$ \\
11 & $22.3 \mathrm{~b}$ & $3,127 \mathrm{~b}$ & $9,368 \mathrm{~b}$ \\
23 & $18.7 \mathrm{~b}$ & $3,635 \mathrm{~b}$ & $14,219 \mathrm{~b}$ \\
45 & $17.4 \mathrm{~b}$ & $2,474 \mathrm{~b}$ & $7,037 \mathrm{~b}$ \\
91 & $21.4 \mathrm{~b}$ & $3,149 \mathrm{~b}$ & $8,364 \mathrm{~b}$ \\
Weedy check & 24 & 63 & 58 \\
CV $(\%)$ & & & \\
\hline
\end{tabular}

${ }^{1}$ Means followed by the same letters do not differ significantly at $\mathrm{P}=.05$ using the paired- $t$ test.

weed competition at Isabela occurred at 13 plants $/ \mathrm{m}^{2}$. This yield $(2,611$ $\mathrm{kg} / \mathrm{ha}$ ) was not significantly different from that of the weedy check $(1,040$ $\mathrm{kg} / \mathrm{ha}$ ). A density of $91 \mathrm{plants} / \mathrm{m}^{2}$ caused the greatest yield reduction (91\%) at Juana Diaz. As expected, highest sweetpotato yield was obtained on weed-free plots-11,823 $\mathrm{kg} / \mathrm{ha}$ at Isabela and $26,724 \mathrm{~kg} / \mathrm{ha}$ at Juana Díaz. One reason for the lower yield at Isabela may be attributed to damage caused by the sweetpotato beetle (Cylas formicarius elegantulus Summers), which was not effectively controlled by the insecticides carbofuran and endosulfan. Another reason for the lower yield at Isabela could be attributed to soil type difference, because San Antón loam is more fertile than Coto clay.

The effect of pigweed on number of tubers followed a similar trend as the effect of pigweed on total weight. At Isabela, average dry weight of pigweed plant was significantly higher at population densities of 4 and 7 plants $/ \mathrm{m}^{2}$. However, at Juana Díaz average dry weight of pigweed plant was significantly higher at population density of $11 \mathrm{plants} / \mathrm{m}^{2}$. The regression analysis between sweetpotato yield and the different pigweed densities showed an inverse linear relationship at both localities. The 
regression equations were as follows: $Y=7886-180 X$ for Isabela and $Y=13,000-149 X$ for Juana Díaz. The correlation coefficients $(r=0.48$ and 0.49 for Isabela and Juana Diaz, respectively) were low but significant at $P=0.05$. The results reported herein and those reported previously (10) strongly suggest that pigweed is a highly competitive weed. To determine how much pigweed can reduce sweetpotato yields, lower population densities must be used in future experiments.

\section{RESUMEN}

La competencia de bledo (Amaranthus dubius) con la batata (Ipomoea batatas)

Para determinar el efecto de la compefencia de diferentes densidades de bledo sobre el rendimiento de la batata se realizaron dos experimentos en los centros de investigación y desarrollo de Isabela y Juana Díaz en 1982-83. Bajo las condiciones naturales de cada localidad la densidad de bledo arrojó una media de 27 plantas $/ \mathrm{m}^{2}$ en Isabela y 91 plantas $/ \mathrm{m}^{2}$ en Juana Díaz. Entre la tercera y la euarta semanas se ajustaron manualmente las siguientes densidades de bledo: $0,4,7,13$ y 27 plantas $/ \mathrm{m}^{2}$ en isabela y $0,11,23,45$ y 91 plantas $/ m^{2}$ en Juana Díaz. El rendimiento de batatas disminuyó significativamente con las densidades de 4 plantas $/ \mathrm{m}^{2}$ en Isabela y de 11 plantas $/ \mathrm{m}^{2}$ en Juana Díaz. El mayor rendimiento de batatas, 11,823 $\mathrm{kg} / \mathrm{ha}$ en Isabela y $27,724 \mathrm{~kg} / \mathrm{ha}$ en Juana Díaz, se obtuvo en las parcelas libres de malezas. El mayor efecto lo causó la densidad de 91 plantas $/ \mathrm{m}^{2}$ ? en Juana Díaz on $\mathbf{9 1 \%}$ de reducción en el rendimiento de batatas. En Isabela, la densidad de 13 plantas $/ \mathrm{m}^{2}$. causó el mayor efecto con $78 \%$ de rendimiento de batatas. El efecto del bledo en el número de batatas siguió una tendencia similar al efecto en peso total. En Isabela el peso seco por planta de bledo fue significativamente mayor en las densidades de 4 y 7 plantas $/ \mathrm{m}^{2}$. En Juana Díaz, el peso seco por planta de bledo fue significativamente mayor en la densidad de 11 plantas $/ \mathrm{m}^{2}$. El análisis de regresión entre el número de plantas de bledo y el rendimiento de batatas demostró una relación lineal inversa en ambas lacalidades.

\section{LITERATURE CITED}

1. Anderson, W. P., 1980. Weed Science: Principles, West Publishing Co., St. Paul, New York, Boston, Los Angeles and San Franciseo.

2. Anonymous, 1988. Facts and Figures on Puerto Rico's Agriculture. 1981/82-1982/83. Commonwealth of Puerto Rico, Department of Agriculture, Santurce, Puerto Rico.

3. Anonymous, 1976. Conjunto Tecnológico para la Produccion de Cosechas Farináceas. Publ. 101, Esta. Exp. Agric. Univ. P. R.

4. Asberry, J. and C. Harvey, 1969. The effect of pigweed on the yield of soybeans. Abst. Proc. SWSS, 22: 96.

5. Hummerton, J. L., 1981. Weed problems and weed control in the Commonwealth Caribbean. PANS 27: 37987.

6. Kasasian, L. and J. Seeyave, 1969. Critical periods of weed competition. PANS 15: 208-12.

7. Labrada, R., 1978. The development of weed control methods for vegetable crops and 
French beans in the Republic of Cuba. Esta. Central Pruebas de Plaguicidas. INRA, Habana, Cuba.

8. Mohammed, E. S. and R. D. Sweet, 1978. Redroot pigweed (Amarunthus retroflexus L.) and tomato (Lycopersicon esculentum L.) competition studies: 1. Influence of plant densities, Abst. 1978. Meet. Weed Sci. Soc. Am. p. 2930.

9. Onwueme, I, C., 1978. The Tropical Tuber Crops. John Wiley and Sons, New York.

10. Semidey-Laracuente, N., L. C. Liu, L. Almodóvar-Vega and H. Ortiz, 1984. La competencia del arrocilo (Echinochloa colonum) con la batata (Ipomoea batatas). Proc. Nineteen Annu. Meet. Caribbean Food Crop Soc. 19: 132-40.

11. Zimdahl, R. L., 1980. Weed Crop Competition-A review. Int. Plant Protec. Center Oregon State Univ, Corvallis, Oregon/USA. 
